Syntax Literate: Jurnal Ilmiah Indonesia p-ISSN: 2541-0849 e-ISSN: 2548-1398

Vol. 5, No. 7, Juli 2020

\title{
EVALUASI PENGGUNAAN ANTIBIOTIKA PADA PENGOBATAN SEPSIS NEONATAL DENGAN METODA GYSSENS DI RSAD SALAK BOGOR TAHUN 2018
}

\author{
Nanik Patminingsih, Dian Ratih Laksmitawati dan Hesty Utami Ramadaniati \\ Fakultas Farmasi Universitas Pancasila Jakarta \\ Email : Niek_P70@yahoo.com, dianratih.ffup@gmail.com, \\ h.ramadaniati@graduate.curtin.edu.au
}

\begin{abstract}
Sepsis is an organ dysfunction that involves life caused by immune dysregulation against infection. The provision of appropriate antibiotics is one of the criteria in the management of sepsis. In neonatal sepsis patients. The study was conducted analytically with a prospective plot. A total of 34 samples of neonatal sepsis patients were monitored for drug therapy. The dominant characteristics of infants that determine sepsis are male babies with a percentage of 59\%, including $62 \%$ Adequate Infant Weight (BBLC), 59\% types of Early Onset Sepsis (EOS), 79\% full term pregnancy and 62\% normal delivery results. The most used antibiotics are a combination of ceftriaxone-gentamicin as much as 50\%, ampicillin-gentamicin as a first-line combination of 35\%, a single ceftriaxone $9 \%$ and a single ceftazidime and a combination of ceftazidime-gentamicin each 3\%. Gyssens evaluation results reported the results of the rationality of antibiotics $18 \%$, irrationality $82 \%$. Statistical results show the value of sig obtained was 0.912> alpha 0.05. This shows that $\mathrm{HO}$ is accepted or that there is no relationship of rationality with the length of days settled. Rational or inappropriate use of a patient is faster or longer in healing.
\end{abstract}

Keywords: Use of antibiotics; neonatal sepsis; Gyssens method

\section{Abstrak}

Sepsis merupakan disfungsi organ yang mengancam kehidupan yang diakibatkan oleh disregulasi imun terhadap infeksi. Pemberian antibiotika yang sesuai merupakan salah satu kriteria dalam tata laksana sepsis. Penelitian ini bertujuan untuk mengevaluasi penggunaan antibiotika pada pasien sepsis neonatal. Penelitian dilakukan secara obsevasi analitik dengan alur prospektif. Sebanyak 34 sampel pasien sepsis neonatal dilakukan pemantauan terapi obat. Karakteristik dominan bayi yang mengalami sepsis adalah bayi laki-laki dengan prosentase 59\%, terdapat 62\% Berat Badan Bayi Cukup (BBLC), 59\% jenis sepsis Early Onset Sepsis (EOS), kehamilan cukup bulan $79 \%$ dan riwayat persalinan normal $62 \%$. Penggunaan antibiotika terbanyak adalah kombinasi seftriakson-gentamisin sebanyak 50\%, kombinasi ampisilin-gentamisin sebagai lini pertama sebanyak $35 \%$, ceftriakson tunggal 9\% serta ceftazidim tunggal dan kombinasi seftazidimgentamisin masing-masing 3\%. Hasil evaluasi Gyssens menunjukkan hasil kerasionalan antibiotika 18\%, ketidakrasionalan 82\%. Hasil statistic menunjukkan 
bahwa nilai sig yang didapat sebesar $0.912>$ alpha 0.05. Hal ini menunjukkan HO diterima atau tidak adanya hubungan rasionalitas dengan lama hari sembuh. Penggunaan rasional atau tidaknya tidak ada hubungannya dengan seorang pasien lebih cepat atau lebih lama dalam penyembuhan.

Kata kunci : Penggunaan antibiotika; sepsis neonatal; metoda Gyssens

\section{Pendahuluan}

Sepsis merupakan disfungsi organ yang mengancam kehidupan (life threatening organ dysfungtion) yang disebabkan oleh disregulasi imun terhadap infeksi. Sepsis dan syok septik merupakan salah satu penyebab morbiditas dan mortalitas (50-60\%) anak yang dirawat di ruang rawat inap dan ruang rawat intensif. Angka kematian lebih tinggi pada anak dengan immunodefisiensi ((IDAI), 2016). Bakteri, virus, jamur, dan protozoa dapat menyebabkan sepsis pada bayi baru lahir ((IDAI), 2016)

Sepsis yang tidak ditangani dengan benar akan menyebabkan kematian pada neonatal. Insiden sepsis di negara berkembang cukup tinggi, menurut perkiraan Word Health Organization (WHO), terdapat 5 juta kematian neonatal setiap tahun dengan angka mortalitas neonatal (kematian dalam 28 hari pertama kehidupan) adalah 34 per 1000 kelahiran, dan 98\% kematian tersebut berasal dari negara berkembang. Penyebab utama kematian (thn 2016) adalah: prematur, komplikasi terkait persalinan (asfixia atau kesulitan bernafas saat lahir), infeksi (apsesi) dan cacat lahir (birth defect) (Achadi, 2019).

Menurut data Dinas Kesehatan propinsi Jawa Barat angka kejadian sepsis neonatal termasuk dalam 10 penyakit terbesar pada penyakit neonatal. Dinas Kesehatan Kabupaten Bogor menyebutkan bahwa jumlah kematian akibat sepsis neonatal tahun 2015 adalah 32 bayi meninggal (4,97\%) ((Dinkes Jabar), 2012). Jumlah sepsis neonatal di Rumah Sakit Angkatan Darat (RSAD) Salak Bogor semakin lama semakin meningkat, menurut data infokes tahun 2018, semester pertama tahun 2017 jumlah sepsis neonatal Rumah Sakit Salak mencapai angka 102 bayi dari 625 bayi yang lahir, semester kedua 2017 jumlah bayi yang menderita sepsis sebanyak 174 bayi dari 702 bayi yang lahir. RSAD Salak bulan April 2017 menjadi pilihan Dinas Kesehatan Kota Bogor dalam pelaksanaan Program EMAS (Expanding Maternal and Newborn Survival) penanganan sepsis neonatal. EMAS adalah program kerjasama antara USAID dan Indonesia yaitu suatu proyek untuk memperluas kelangsungan hidup ibu dan bayi, dengan Perjanjian Kerjasama Nomor AID-497-A-11-00014, adalah program lima tahun, \$55 juta untuk mendukung Pemerintah Indonesia untuk mengurangi kematian ibu dan bayi baru lahir. EMAS bekerja dengan lembaga pemerintah Indonesia (nasional, provinsi dan lokal), Organisasi masyarakat sipil, fasilitas kesehatan umum dan swasta, organisasi profesi kesehatan, dan sektor swasta (Para P, 2017).

Penggunaan antibiotika secara umum di RSAD Salak belum pernah dievaluasi, oleh karena itu penulis akan melakukan evaluasi antibiotika pada penanganan kasus 
sepsis neonatal di RSAD Salak, sehingga perlu dilakukan penelitian/evaluasi terhadap pola peresepan antibiotika di RSAD Salak Bogor khususnya pada sepsis neonatal.

\section{Metode Penelitian}

Penelitian ini merupakan studi observasi analitik dengan alur prospektif yaitu pengamatan langsung penderita pasien sepsis neonatal. Lokasi penelitian dilakukan di Rumah Sakit Angkatan Darat Salak Bogor selama empat bulan yaitu bulan April sampai Juli 2018.

Populasi dalam penelitian ini diambil dari pasien sepsis neonatal ruang bayi di Rumah Sakit Angkatan Darat Salak Bogor. Pasien yang dijadikan subyek penelitian berjumlah 34 sampel, baik yang berasal dari persalinan diluar RSAD Salak maupun yang lahir di RSAD Salak, yaitu seluruh pasien terdiaqnosa sepsis neonatal dan menerima pengobatan dengan menggunakan antibiotika. Data yang diambil meliputi data demografi dan data utama. Data demografi meliputi nomor RM, jenis kelamin, umur pasien, berat badan, alamat, penanggungjawab. Data utama meliputi kondisi saat lahir, riwayat kehamilan, jenis kelahiran (normal atau caesar) serta hasil laboratorium. Dalam penelitian data pasien sepsis baru lahir diambil dari pasien yang sedang dirawat yaitu: nama bayi, no rekam medik, jenis kelamin, berat badan, indikasi medis, jenis sepsis, tanggal masuk dan tanggal keluar, jenis persalinan, anak ke berapa? kelas perawatan, cara pembayaran, antibiotika yang digunakan. Data yang terkumpul akan diperiksa/divalidasi kemudian dilakukan pengolahan untuk di analisis. Data demografi dan profil pengobatan dianalisis dengan Uji univariat secara deskriptif. Evaluasi data penggunaan antibiotika dilakukan dengan metoda Gyssens untuk mengetahui rasionalitas penggunaan antibiotika yang digunakan dalam pengobatan sepsis neonatal. Hasil evaluasi Gyssens kemudian dijadikan dasar untuk melakukan analisis uji bivarait dalam mencari hubungan antara rasionalits pengobatan dengan kesembuhan pasien dengan Uji t sampel independen (Independent T-Test) dan mengetaui perbedaan rasionalits pengobatan dengan hari kesembuhan pasien dengan Uji korelasi spearman's rho (Corellation Spearman's rho test).

\section{Hasil dan Pembahasan}

\section{Profil pasien}

Profil dari 34 pasien meliputi jenis kelamin pasien, berat badan pasien, jenis sepsis neonatal, riwayat kehamilan dan riwayat persalinan yang disajikan dalam tabel 1. Berdasarkan jenis kelamin, pasien sepsis neonatal laki-laki ada sebanyak 19 atau 59\% dan perempuan 15 atau 41\%. Penderita sepsis neonatal pada penelitian ini lebih banyak laki-laki daripada perempuan. Hal ini sejalan dengan penelitian yang dilakukan Hafith dkk yang dilakukan di RSCM pada tahun 2014, perbandingan rasio pasien sepis neonatal 1,25:1 (Giofani, Oyong, \& Inayah, 2016). Sedangkan pada penelitilan lain yang dilakukan Geovani R, Oyong $\mathrm{N}$, Inayah, dengan judul evaluation usage of antibiotic to sepsis neonatus patient in RSUD Arifin Achmad Province Riau. Penelitian dilakukan pada 68 pasien yang mendapatkan hasil jumlah 
bayi laki-laki sebanyak 29 (42,6\%) dan bayi perempuan 39 (57,4\%) (Giofani et al., 2016). Dalam sebuah hipotesis dijelaskan bahwa pasien laki-laki lebih banyak daripada perempuan karena adanya faktor-faktor lain yang mengatur sintesis immunoglobulin pada kromosom $\mathrm{X}$, oleh karena itu adanya dua kromosom pada perempuan membuat fungsi pertahanan terhadap infeksi lebih besar (Wisnumurti, 2012).

Dilihat dari proporsi evaluasi berat badan pasien baru lahir yang paling tinggi adalah Berat Bayi Lahir Cukup (BBLC) yaitu sebanyak 21 pasien atau 62\%, sedangkan Berat Bayi Lahir Ringan (BBLR) sebanyak 13 pasien atau $38 \%$. Penelitian yang dilakukan Geovani dkk (2016) tidak sama dengan penelitian ini, karena hasil yang diperoleh pada berat lahir cukup berjumlah 29 atau 42,6\% dari 68 jumlah pasien yang di teliti. Sedangkan jumlah berat badan lahir ringan berjumlah 39 atau 57,8\%. Penelitian yang dilakuakan oleh Ika Popi Sundani 2017 menyatakan bahwa dari 120 ibu yang memiliki bayi umur $\leq 1$ tahun tanpa memandang usia kehamilan, sebagai kelompok kasus (BBLR) sejumlah 30 ibu (25\%) dan sebagai kelompok kontrol (tidak BBLR) sejumlah $90 \mathrm{ibu}$ (75\%). Dari 11 faktor yang memiliki hubungan dengan kejadian BBLR, terdapat 5 faktor dominan yangberpengaruh untuk mengakibatkan ibu mengalami terjadinya BBLR, yaitu variabel pengetahuan ibu, paritas, status gizi ibu, Frekuensi pemeriksaan ANC dan lama kerja (Sundani, 2020). Pada penelitian lain yang dilakukan oleh Haryani dkk bahwa kelahiran dengan BBLR lebih tinggi yaitu 69,1\% daripada BBLC (Haryani \& Apriyanti, 2016). Pada penelitian Manuaba dijelaskan bahwa pada bayi dengan BBLR memiliki pusat pengaturan pernapasan yang belum sempurna dengan surfaktan paru-paru masih kurang menyebabkan perkembangan paru tidak sempurna. Otot-otot pernapasan dan tulang iga yang masih lemah mengakibatkan kurangnya suplai oksigen ke otak. Jika kurangnya kadar oksigen maka kuman aerob mudah berkembang dan mudah untuk terjadinya infeksi (Manuaba, 2012).

Tabel I Profil Pasien Infeksi Sepsis Neonatal di RSAD Salak Bogor Tahun 2018 Periode April-Juli 2018.

\begin{tabular}{clcc}
\hline No & \multicolumn{1}{c}{ Karakteristik } & Jumlah & Prosentase(\%) \\
1 & Jenis Kelamin & 19 & 59 \\
& Laki-laki & 15 & 41 \\
2 & $\begin{array}{l}\text { Perempuan } \\
\text { Berat Badan Pasien }\end{array}$ & 13 & 38 \\
& Berat Badan Lahir Ringan (BBLR) & 21 & 62 \\
& Berat Badabn Lahir Cukup (BBLC) & & 59 \\
3 & Jenis Sepsis Neonatal & 19 & 41 \\
& Early Onset Sepsis (EOS) & 15 & 79 \\
4 & Lost Onset Sepsis (LOS) & 27 & 21 \\
& Riwayat Usia Kehamilan & 7 & 62 \\
& Kehamilan Cukup Bulan (KCB) & & 38 \\
5 & Kehamilan Kurang Bulan (KKB) & 21 & 100 \\
& Riwayat Persalinan & 13 & \\
& Lahir Normal & & \\
& Riwayat Pulang & 34 & \\
\hline
\end{tabular}


Berdasarkan timbulnya gejala klinis jenis sepsis neonatal didasarkan pada waktu paparan dibagi menjadi dua, yaitu sepsis awitan dini (SAD)/early onset sepsis (EOS) sebanyak 19 pasien atau 59\% dan sepsis awitan lambat/los onset sepsis sebanyak 15 pasien atau $41 \%$. Hal ini sejalan dengan penelitian yang dilakukan oleh Haryani S. dkk yaitu dengan hasil $81 \%$ dari 42 bayi yang menerima pengobatan antibiotika (Haryani \& Apriyanti, 2016). Pada penelitian lain yang dilakukan oleh Wilar R dkk juga diperoleh insiden SAD lebih tinggi yaitu dari 72 bayi sebanyak 58 bayi didiagnosa sepsis awitan dini (Wilar, Kumalasari, Suryanto, \& Gunawan, 2016). Tingginya angka kejadian sepsis pada SAD, dengan anggapan bahwa infeksi SAD ditularkan perinatal dari ibunya, sedangkan SAL didapatkan pascanatal dari lingkungan (Wilar et al., 2016).

Proporsi penderita sepsis neonatal usia kehamilan didapat dengan kehamilan cukup bulan berjumlah 27 pasien atau $79 \%$ dan usia kehamilan kurang bulan sebanyak 7 pasien atau 21\%. Pada penelitian yang dilakukan oleh Haryani S. dkk menunjukkan hasil jumlah sepsis neonatal yang disebabkan oleh usia kehamilan kurang bulan berjumlah 27 pasien atau 64,3\% dari 42 pasien yang diteliti (Haryani \& Apriyanti, 2016). Pada bayi dengan prematur, pematangan organ-organ tubuhnya kurang sempurna sehingga sangat peka terhadap infeksi, gangguan pernapasan, trauma kelahiran, hipotermia, dan sebagainya (Roeslani, Amir, Nasrulloh, \& Suryani, 2016). Selain itu bayi prematur beresiko tinggi mengalami infeksi karena masih belum sempurnanya pembentukan imun seperti, rendahnya fagositosis, aktifitas kemotaksis yang terbatas serta penurunan produksi sitokin proinflamasi dan antiinflamasi. Barier kulit pada bayi prematur juga lebih tipis dan lemah dalam mencegah mikroorganisme patogen masuk ke dalam jaringa yang lebih dalam dibandingkan dengan bayi yang lahir cukup bulan. Selain itu bayi prematur dengan BBLR memiliki risiko yang lebih besar untuk mengalami masalah diantaranya pematangan organ tubuhnya (hati, paru, enzim, pencernaan, otak, daya pertahanan tubuh terhadap infeksi) belum sempurna, maka bayi BBLR sering mengalami komplikasi yang berakhir dengan kematian (Rahmawati, Mayetti, \& Rahman, 2018).

Proporsi penderita sepsis neonatal pada riwayat persalinan tertinggi yaitu lahir normal sebanyak 21 pasien atau 62\%, kemudian lahir sesar sebanyak 13 pasien atau 48\%. Penelitian ini tidak sejalan dengan yang dilakuhan Haryani dkk dengan hasil lahir non spontan 59,5\% dari 42 pasien sepsis neonatal (Haryani \& Apriyanti, 2016). Tingginya angka kejadian pada ibu dengan riwayat persalinan spontan dapat diduga bahwa bayi sepsis neonatal bukan hanya dapat ditularkan ketika dalam kandungan, tetapi juga dapat ditularkan pada proses persalinan (Wisnumurti, 2012). Berdasarkan hasil penelitian bahwa bayi yang lahir dengan sesar juga beresiko untuk terjadi sepsis neonatal. Hal ini terjadi karena kontaminasi kuman yang terjadi setelah lahir seperti penggunaan alat saat dilakukan pertolongan persalinan (Manuaba, 2012).

Proporsi penderita sepsis neonatal pada riwayat pulang adalah sembuh dengan jumlah 34 pasien atau 100\%. Pasien dinyatakan sembuh apabila tanda dan gejala sepsis sudah tidak muncul, pasien menunjukkan perbaikan seperti pada umumnya 
keadaan bayi baik, suhu tubuh kembali normal, percepatan pernapasan normal, denyut nadi normal.

\section{Profil Peresepan antibiotika}

Profil peresepan antibiotika menjelaskan tentang pemakaian golongan dan jenis antibiotika yang digunakan dalam pengobatan sepsis neonatal, rute pemberian serta durasi pemberian antibiotika yang diresepkan pada pasien sepsis neonatal di ruang bayi RSAD Salak Bogor periode April-Juni 2018 sebagaimana disajikan pada tabel 2. Tabel tersebut menunjukkan jenis dan golongan antibiotika yang digunakan pada pengobatan sepsis neonatal periode April-Juni 2018 baik tunggal maupun kombinasi. Golongan yang sering digunakan adalah kombinasi ceftriaksongentamisin sebanyak 17 kasus (50\%), hal ini tidak sesuai dengan yang dianjurkan oleh SPO RSAD Salak Bogor 2015 dan juga dianjurkan oleh Intensive Care Unit Neonatal Clinical Guedeline, Ashford and St. Peter's Hospital NHS tahun 2015, yang menyatakan bahwa kombinasi ampisilin-gentamisin merupakan pengobatan lini pertama pada pengobatan sepsis neonatal.

Tabel 2 Golongan dan Jenis Antibiotika Pada Pasien Sepsis Neonatal Rawat Inap di RSAD Salak Periode April-Juni 2018.

\begin{tabular}{clcc}
\hline No. & \multicolumn{1}{c}{ Tolongan dan Jenis Antibiotika } & \begin{tabular}{c} 
Jumlah satuan \\
\cline { 2 - 3 } 1.
\end{tabular} & $\begin{array}{c}\text { Prosentase } \\
(\%)\end{array}$ \\
\hline \multirow{2}{*}{ Penisilin-aminoglikosidas } & Resep $(\mathrm{R} /)$ & \\
& Ampisilin-gentamisin & 12 & 35 \\
\hline & Sefalosforin-Aminoglikosida & & \\
2. & Ceftriakson & 3 & 9 \\
Ceftriakson-gentamisisn & 17 & 50 \\
Ceftazidim & 1 & 3 \\
Ceftazidim-gentamisisn & 1 & 3 \\
Jumlah & 34 & 100 \\
\hline
\end{tabular}

Hasil penelitian ini juga tidak sejalan dengan yang dilakukan Haryani dkk yang mendapatkan hasil bahwa yang menduduki peringkat tertinggi yaitu 33\% pemakaian antibiotika lini pertama yaitu amoksisilin-gentamisin (Haryani \& Apriyanti, 2016). Pada penelitian lain yang dilakukan oleh Giovani dkk menyebutkan pemakaian paling banyak adalah golongan aminoglikosida yaitu 35\% (Giofani et al., 2016). Hal ini dikarenakan pasien yang di rawat inap di RSAD Salak Bogor berasal dari poliklinik yang berarti pasien yang lahir di luar RSAD Salak atau yang lahir di RSAD Salak tetapi sudah pulang, sehingga pengobatannya langsung lini ke-2 yaitu kombinasi ceftriakson-gentamisin. Kemudian disusul dengan kombinasi ampisilingentamisin sebanyak 12 kasus (35\%) yang merupakan lini pertama dalam pengobatan sepsis neonatal.

Ceftriakson tunggal 3 kasus (9\%), ceftazidim tunggal 1 kasus (3\%), kombinasi ceftazidim-gentamisin sebanyak 1 kasus (3\%). Pada penelitian ini diperoleh 7 variasi peresepan antibiotika yang digunakan dalam pengobatan sepsis neonatal periode April-Juni 2018. Kebanyakan dari seluruh pengobatan 30 dari 34 kasus yang diteliti 
menggunakan antibiotika kombinasi, karena memang sesuai yang disarankan oleh SPO RSAD Salak Bogor dan juga IDAI 2009. Pada penelitian ini terdapat 4 kasus antibiotika kombinasi (switching), dan 30 kasus tidak dilakukan penggantian antibiotika. Sebanyak 4 kasus yang dilakukan penggantian (switching) adalah 1 kasus penggantian dari cefotaksim (48 jam) menjadi ceftriakson-gentamisin ( 8 hari), 1 kasus penggantian dari ampisilin (72 jam) menjadi ceftazidim (5 hari), 2 kasus penggantian dari ceftriakson-gentamisin menjadi ceftazidim. Hal ini sesuai dengan yang dianjurkan baik oleh SPO RSAD Salak Bogor 2015 dan IDAI 2009, yaitu bila pasien tidak ada perbaikan pada lini 1 lanjut ke lini 2 dan bila belum sembuh juga dilanjutkan dengan lini ke-3.

\section{Rute Penggunaan antibiotika}

Rute pemberian antibiotika pada pengobatan sepsis neonatal di RSAD Salak Bogor menggunakan rute intravena. Rute intravena diberikan mengingat kondisi bayi baru lahir yang tidak memungkinkan diberikan antibiotika melalui rute oral. Selain itu diberikan melalui rute intravena karena sepsis merupakan inveksi berat yang memerlukan bioavailabilitas tinggi untuk melawan bakteri yang tersebar dalam darah.

\section{Durasi Penggunaan antibiotic}

Terdapat berbagai macam durasi penggunaan antibiotika yang diberikan pada pasien sepsis neonatal, mulai dari 6 hari sampai 12 hari penggunaan antibiotika sebagaimana disajikan pada gambar 1 dan tabel 3. Durasi tersingkat adalah 6 hari dengan prosentase $3 \%$ dan durasi terlama adalah 12 hari dengan prosentasi $9 \%$ dari keseluruhan kasus. Durasi penggunaan antibiotika terbanyak adalah 7 hari yaitu dengan prosentasi $44 \%$ dari keseluruhan kasus.

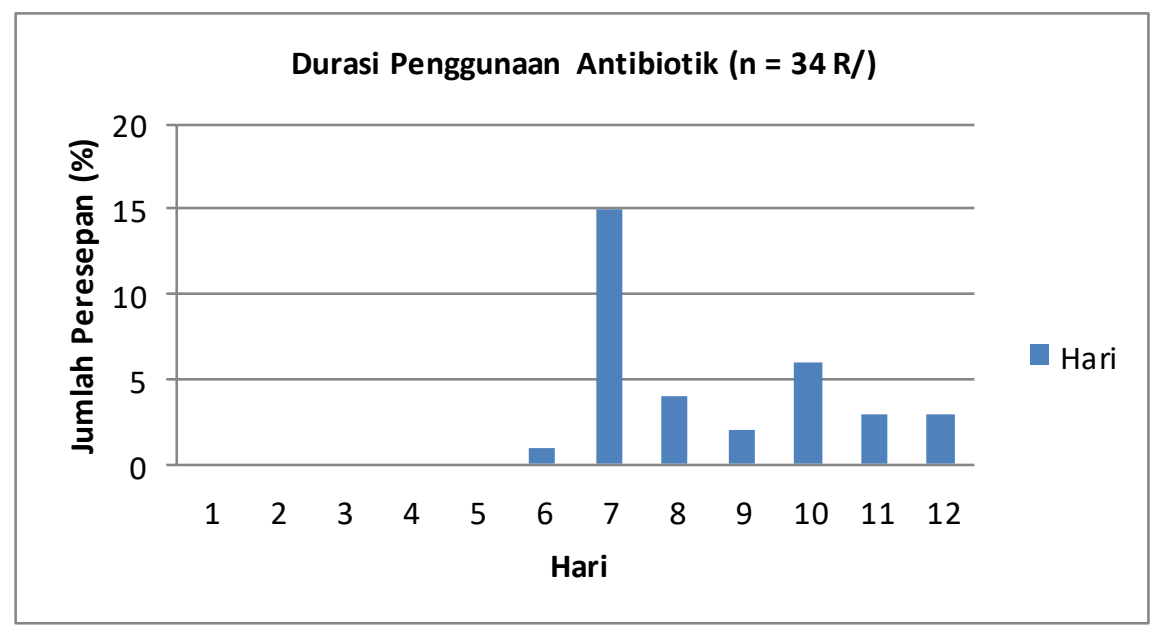

\section{Gambar 1 \\ Distribusi Durasi Pemberian Antibiotika Pada Sepsis Neonatal Rawat Inap di RSAD Salak Bogor Periode April- Juni 2018}


Tabel 3 Distribusi Durasi Pada Tiap Jenis Penggunaan antibiotika Pada Pasien sepsis Neonatal Rawat Inap di RSAD Salak Bogor Periode April-Juli 2018

\begin{tabular}{ccccccc}
\hline Durasi & $\begin{array}{c}\text { Ampisilin- } \\
\text { gentamisin }\end{array}$ & Ceftriaxon & $\begin{array}{c}\text { Ceftriakson- } \\
\text { gentamisin }\end{array}$ & Ceftazidim & $\begin{array}{c}\text { Ceftazidim- } \\
\text { gentamisin }\end{array}$ & Jumlah \\
\hline 6 hari & & & 1 & & & 1 \\
7 hari & 6 & 2 & 6 & 1 & & 15 \\
8 hari & & & 3 & & 1 & 4 \\
9 hari & 2 & & 3 & & & 2 \\
10 hari & 3 & 2 & & 1 & 6 \\
11 hari & & & 2 & & & 3 \\
12 hari & 1 & & 17 & 1 & 2 & 34 \\
Jumlah & 12 & 2 & & & & \\
\hline
\end{tabular}

\section{Evaluasi Penggunaan Antibiotika Dengan Metode Gyssens}

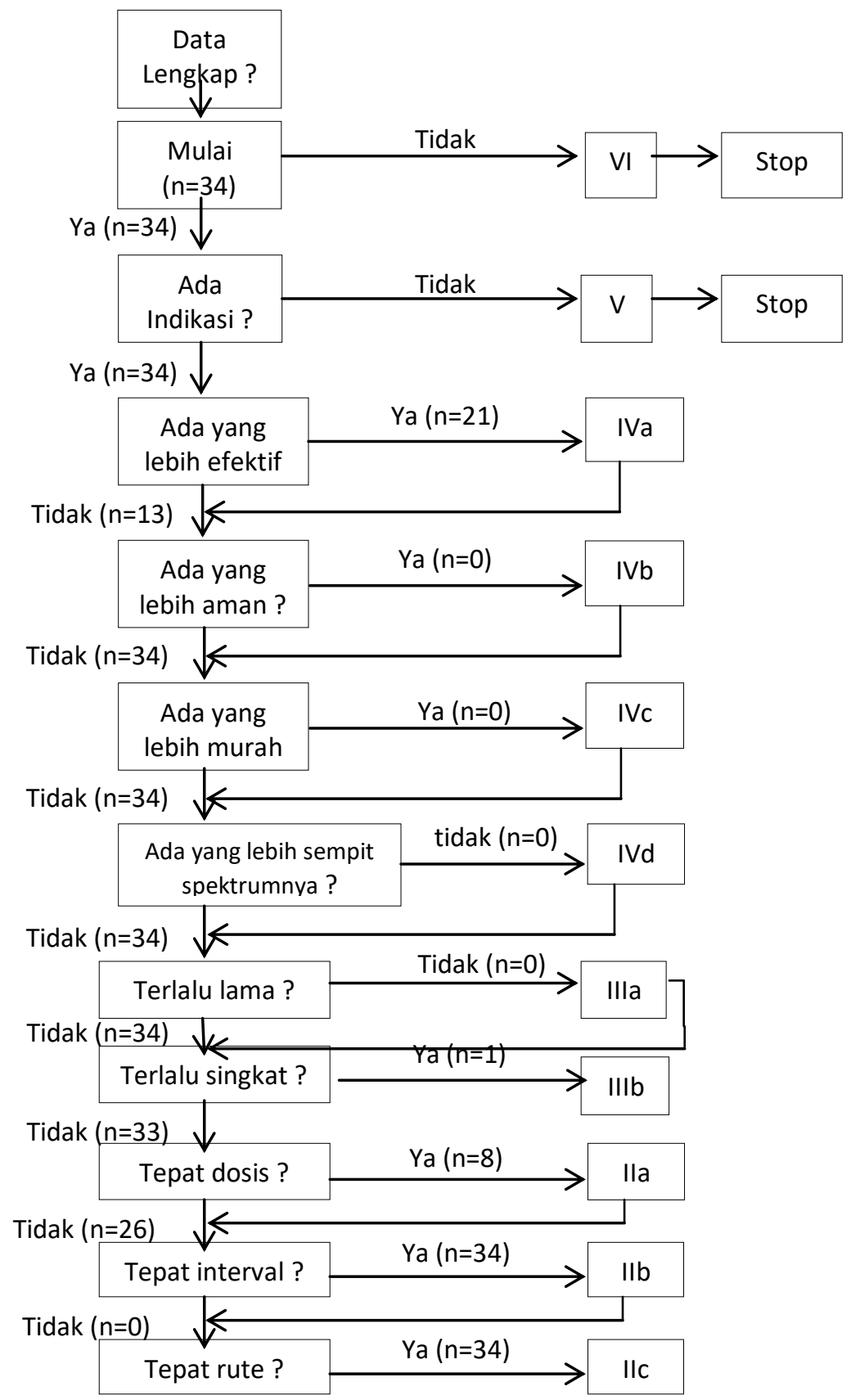




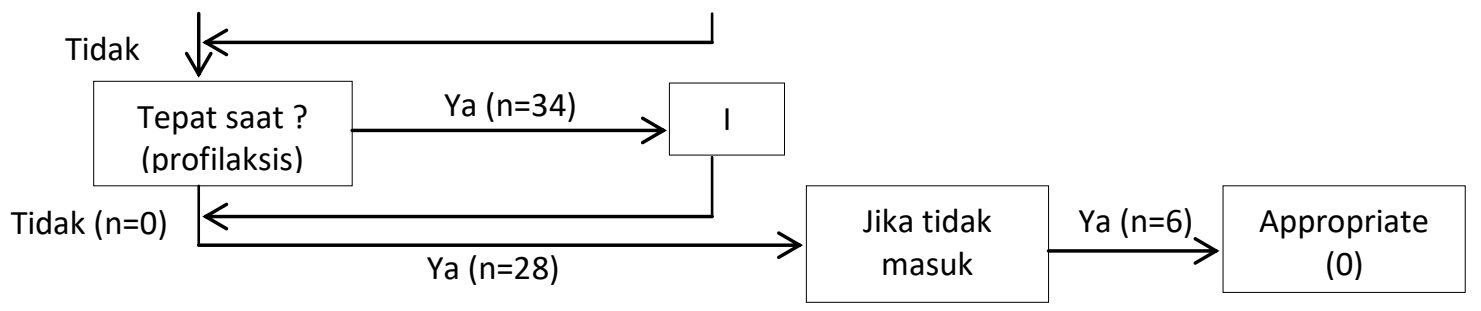

Gambar 2

Distribusi Ketepatan Peresepan Antibiotika Berdasarkan Metoda Gyssens di RSAD Salak Bogor Periode April-Juli 2018

Evaluasi penggunaan antibiotika dengan menggunakan metode Gyssens dan Mers yang dinilai dengan 12 subkatagori yang dinyatakan dalam satuan peresepan dalam alur Gyssens sebagaimana ditunjuukan pada gambar 2.

Menurut Dina Sintia Pamela dalam penelitiannya, Metode Gyssens digunakan untuk mengevaluasi ketepatan penggunaan antibiotika. Tujuan evaluasi tersebut adalah agar pasien mendapatkan obat yang paling efektif, aman, murah dengan regimen yang tepat dan menghindari resistensi (Pamela, 2011).

\begin{tabular}{|c|c|c|c|c|c|c|}
\hline $\begin{array}{l}\text { Katagori } \\
\text { Gyssens }\end{array}$ & $\begin{array}{l}\text { Ampisilin- } \\
\text { Gentamisin }\end{array}$ & Ceftirakson & $\begin{array}{l}\text { Ceftirakson- } \\
\text { Gentamisin }\end{array}$ & Ceftazidim & $\begin{array}{l}\text { Ceftazidim- } \\
\text { gentamisin }\end{array}$ & Jumlah \\
\hline \multicolumn{7}{|l|}{ VI } \\
\hline \multicolumn{7}{|l|}{ V } \\
\hline IVa & & 3 & 16 & 1 & 1 & 21 \\
\hline \multicolumn{7}{|l|}{$\mathrm{IVb}$} \\
\hline \multicolumn{7}{|l|}{ IVc } \\
\hline \multicolumn{7}{|l|}{ IVd } \\
\hline \multicolumn{7}{|l|}{ IIIa } \\
\hline IIIb & & & 1 & & & 1 \\
\hline IIa & 6 & & & & & 6 \\
\hline \multicolumn{7}{|l|}{$\mathrm{IIb}$} \\
\hline \multicolumn{7}{|l|}{ IIc } \\
\hline \multicolumn{7}{|l|}{ I } \\
\hline 0 & 6 & & & & & 6 \\
\hline Jumlah & 12 & 3 & 17 & 1 & 1 & 34 \\
\hline
\end{tabular}

Pada tabel 4 menunjukkan hasil 6 peresepan antibiotika memenuhi katagori 0 (penggunaan tepat), 6 peresepan antibiotika kombinasi termasuk dalam katagori lia (dosis pemberian tidak tepat) , 1 peresepan antibiotika kombinasi dalam katagori IIIb (pemberian terlalu singkat), 21 peresepan antibiotika kombinasi dalam katagori Iva (ada antibiotika lain yang lebih efektif). Pada penelitian ini tidak ditemukan antibiotika yang memenuhi katagori I (tidak tepat saat profilaksis), katagori Iib 
(interval pemberian tidap tepat), katagori IIc (rute pemberian tidak tepat), katagori IIIa (pemberian terlalu lama), katagori IVb (ada antibiotika yang lebih aman/kurang toksik), katagori IVc (ada antibiotika yang lebih murah), katagori IVd (ada antibiotika yang lebih sempit spektrumnya), katagori $\mathrm{V}$ (penggunaan antibiotika tanpa indikasi ), katagori VI ( rekam medis tidak lengkap untuk di evaluasi).

Hasil yang disajikan pada tabel 4 tersebut menunjukkan bahwa hasil evaluasi peresepan antibiotika dengan kriteria tepat yaitu katagori 0 sebanyak 6 pasien (18\%) adalah kombinasi ampisilin-gentamisin yang merupakan antibiotika lini pertama yang disarankan dalam SPO RSAD Salak Bogor dan IDAI 2009.. Antibiotika yang paling banyak digunakan dalam peresepan kasus sepsis neonatal adalah kombinasi ceftriakson-gentamisin sebanyak 17 kasus (50\%). Terdapat 6 kasus (18\%) peresepan antibiotika yang termasuk dalam katagori IIa (dosis pemberian antibiotika tidak tepat) terdiri dari kombinasi ampisilin-gentamisin. Terkait durasi pemberian antibiotika dalam peresepan antibiotika termasuk dalam katagori IIIa (pemberian antibiotika terlalu lama) tidak ada kasus. Termasuk dalam katagori IIIb (pemberian antibiotika terlalu singkat) terdiri dari 1 kasus yaitu kombinasi ceftriaksongentamisin. Terdapat kasus yang termasuk dalam katagori IVa (ada antibiotika yang lebih efektif) yaitu 21 kasus (65\%).

Kajian literatur ketepatan peresepan pada penelitian ini akan disajikan per katagori Gyssens sebagai berikut:

1. Rekam medis pasien tidak lengkap dan tidak dapat dievaluasi (katagori VI).

Pada penelitian ini karena bersifat prospektif jadi tidak ada rekam medis yang tidak lengkap. Berjumlah 34 kasus pasien sepsis neonatal dengan data rekam medis terisi lengkap data-data pasien sepsis neonatal.

2. Pemberian antibiotika tanpa indikasi (katagori V).

Pada penelitian ini tidak ada pemberian antibiotika tanpa indikasi, karena antibiotika tanpa indikasi dapat diartikan pemberian antibiotika tidak diperlukan bagi pasien tersebut. Tanda-tanda infeksi bakteri sepsis neonatal antara lain ((IDAI), 2016):

a. Infeksi: meliputi

1). Faktor predisposisi infeksi

2). Tanda atau bukti infeksi yang sedang berlangsung

3). Respon inflamasi

b. Tanda disfungsi/gagal organ.

Berdasarkan hasil evaluasi tidak ditemukan peresepan pasien sepsis neonatal pada katagori ini.

3. Ada antibiotika lain yang lebih efektif (katagori IVa).

Ada antibiotika lain yang lebih efektif dapat diartikan ada antibiotika yang bisa memberikan efek terapi yang lebih optimal dan lebih direkomendasikan oleh instansi yang berwenang seperti IDAI, Kemenkes, WHO. Menurut evaluasi pada penelitian ini yang termasuk dalam katagori IVa sebanyak 21 kasus yang terbanyak adalah kombinasi ceftriakson-gentamisin sebanyak 17 kasus (50\%), 3 
kasus pemberian ceftriakson tunggal, 1 kasus ceftazidim tunggal dan 1 kasus kombinasi ceftazidim-gentamisin. Peresepan antibiotika tersebut masuk dalam katagori IVa karena ceftriakson merupakan untuk lini ke-2 dan ceftazidim untuk lini ke-3. Menurut SPO RSAD Salak Bogor tahun 2015 peresepen lini pertama adalah kombinasi ampisilin-gentamisin, Lini ke-2 ceftiakson/cefotaksim, dan lini ke-3 ceftazidim.

4. Ada antibiotika lain yang lebih aman/kurang toksik (katagori IVb).

Ada tidaknya antibiotika yang lebih aman/kurang toksik dilihat dari keamanan antibiotika tersebut terhadap pasien seperti interaksi obat yang menimbulkan efek merugikan kepada pasien atau ada penggunaan antibiotika dengan kontraindikasi dengan kondisi pasien.

5. Ada antibiotika lain yang lebih aman/kurang toksik (katagori IVc).

Evaluasi pada katagori ini yaitu dengan membandingkan obat yang digunakan pasien di RSAD Salak Bogor dengan brand name dari setiap antibiotika. Pada penelitian ini semua antibiotika yang digunakan adalah antibiotika generik yang harganya lebih murah jika dibandingkan dengan yang brand name, sehingga jika pengobatan menggunakan antibiotika lini pertama pasti tidak ada yang masuk katagori ini.

6. Ada antibiotika lain dengan spectrum lebih sempit (katagori IVd).

Pemilihan antibiotika berdasarkan dengan spectrum harus dilakukan dengan uji kultur darah dari pasien atau berdasarkan pola kuman setempat. Pada penelitian ini tidak ada satupun yang menjalani uji kultur darah, sehingga pengobatan hanya dilakukan berdasarkan empiris dan antibiotika empiris yang digunakan berdasarkan SPO RSAD Salak Bogor, dan penatalaksanaannya sudah sesuai dengan yang disarankan oleh IDAI, 2016 dan WHO, 2012. Antibiotika yang digunakan pada penelitian ini adalah antibiotika yang spektrum luas karena kuman penyebab infeksi pada pasien tidak diketahui, sehingga terapi yang digunakan adalah terapi empiris. Tidak ada antibiotika pada katagori ini karena terapi empiris sudah sesuai dengan yang tercantum dalam literatur.

7. Pemberian antibotika terlalu lama (katagori IIIa).

Durasi penggunaan antibiotika pada setiap pasien berbeda-beda tergantung dari kondisi pasien dan tingkat keparahan penyakit. Menurut SPO RSAD Salak Bogor durasi penggunaan antibiotika sepsis neonatal adalah 7 hari untuk infeksi bakteri gram positif dan minimal 14 hari untuk infeksi gram negatif, bila klinik baik. Pada penelitian ini tidak ada yang masuk pada katagori ini, karena sudah sesuai dengan yang disarankan pada literatur.

8. Pemberian antibiotika terlalu singkat (katagori IIIb).

Durasi penggunaan antibiotika pada setiap pasien berbeda-beda, tergantung dari kondisi pasien dan tingkat keparahan penyakit. Menurut SPO RSAD Salak Bogor durasi pemberian antibiotika adalah 7 hari untuk infeksi bakteri gram positif dan minimal 14 hari untuk infeksi bakteri gram negatif, bila klinis baik. Pada penelitian ini terdapat 1 kasus pemberian antibiotika dengan durasi singkat yaitu 
pada data pasien bayi 16 yaitu penggunaan antibiotika ceftriaksin 2 hari dan antibiotika kombinasi seftriakson-gentamisin selama 4 hari, jadi total durasi penggunaan antibiotika selama 6 hari.

9. Dosis antibiotika kurang tepat (katagori IIa).

Pemberian dosis antibiotika kurang tepat, bisa dikarenakan lebih dari dosis yang disarankan atau kurang dari dosis yang disarankan. Dosis yang terlalu tinggi dapat mengakibatkan efek toksik dan dosis yang terlalu rendah tidak menghasilkan efek terapi yang diharapkan. Berdasarkan evaluasi penggunaan antibiotika pada penelitian ini yang termasuk dalam katagori ini ada 26 kasus yaitu:

a. Pemberian antibiotika terlalu tinggi sebanyak 15 kasus terdiri dari:

Pemberian antibiotika ceftriakson -gentamisin pada kasus 2, 4, 6, 10, 11, 12, 13, 14, 16, 23, 24, 26, 28, 31 dan 33.

b. Pemberian antibiotika terlalu rendah sebanyak kasus terdiri dari:

Pemberian ntibiotika ampisilin-gentamisin pada kasus 7, 8, 15, 18, 19, 20, 21, 29, 30 dan 34.

10. Interval pemberian antibiotika tidak tepat (katagori IIb).

Pemberian antibiotika tidak tepat interval bisa dikarenakan lebih atau kurang interval yang disarankan oleh literature. Berdasarkan hasil evaluasi tidak terdapat hasil yang termasuk dalam katagori ini.

11. Rute pemberian antibiotika tidak tepat (katagori IIc).

Ketepatan rute pemberian antibiotika merupakan indikator suatu ketepatan dalam sebuah terapi. Rute pemberian obat harus dipilih rute yang paling aman dan bermanfaat bagi pasien. Rute pemberian dikatakan tepat apabila sesuai dengan yang disarankan oleh literatur. Berdasarkan hasil evaluasi pemberian antibiotika tidak ada yang tidak tepat rute pemberiannya.

12. Pemberian antibiotika tidak tepat profilaksis (katagori I).

Waktu pemberian antibiotika dievaluasi tiap hari saat pemberian antibiotika. Misalkan pemberian ampisilin diberikan 2 kali sehari per 12 jam, maka jika pemberian pertama jam 07.00 dan pemberian kedua pada jam 20.00, maka pemberian antibiotika tersebut tidak lolos katagori I karena waktu pemberian tidak tepat. Berdasarkan hasil evaluasi tidak ada antibiotika yang termasuk dalam katagori I.

13. Apropiate/tepat (katagori 0).

Peresepan antibiotika disebut tepat jika memenuhi tepat diagnosis, tepat indikasi penyakit, tepat pemilihan obat, tepat dosis, tepat rute pemberian, tepat interval pemberian, tepat lama pemberian, waspada efek samping, tepat informasi dan tepat penilaian kondisi pasien (Kemenkes, 2011). Berdasarkan hasil evaluasi penggunaan antibiotika yang termasuk dalam katagori 0 adalah peresepan kombinasi antibiotika ampisilin-gentamisin yaitu ditemukan pada kasus 1, 9, 17, 19, 27, 32. Peresepan antibiotika yang termasuk dalam katagori ini adalah yang lolos pada katagori I-VI, sehingga termasuk katagori 0. 


\section{Analisis Data}

\section{a. Hubungan antara rasionalitas dengan kesembuhan}

Analisis data dilakukan untuk mengetahui hubungan antara rasionalitas penggunaan antibiotika dengan kesembuhan pasien. Dari evaluasi data dengan metoda Gyssens diperoleh hasil rasionalitas pengobatan yaitu katagori 0 sebanyak 6 pasien dari 34 kasus (18\%). Sedangkan pada pengobatan dari 34 pasien yang pulang rawat inap dinyatakan sembuh $100 \%$.

Hasil analisis hubungan antara kesembuhan dengan rasionalitas dianalisis dengan menggunakan uji t sampel independen (Independent T-Test). Tujuannya untuk melihat apakah ada perbedaaan kesembuhan berdasarkan rasionalaitas yaitu antara sembuh rasional dan sembuh tidak rasional. Namun penggunaan uji $t$ didasarkan dua asumsi yaitu kedua kelompok memiliki varian yang sama (equal variance assumed) dan kelompok memiliki varian yang tidak sama (equal variance no assumed). Uji kesamaan dua varian (uji homogenitas) menggunakan uji levene, dengan kriteria uji:

1. Jika nilai $\mathrm{p}<$ alpha $(0.05)$, maka varian berbeda

2. Jika nilai $\mathrm{p}>$ alpha (0.05), maka varian sama

Hasil uji varian dapat dilihat pada Tabel 5. di bawah ini:

\section{Tabel 5 Hasil uji kesamaan varian (homogenitas)}

\begin{tabular}{cc}
\hline Nilai F & Probabilitas $(\mathrm{P})$ \\
\hline 10.421 & 0.003 \\
\hline
\end{tabular}

Berdasarkan uji Levene (Levene's Test), seperti terlihat pada Tabel 1 di atas, diperoleh nilai $\mathrm{p}=0.003<$ alpha (0.05). Hal ini menunjukan kedua kelompok memiliki varian yang berbeda, dengan demikian nilai t yang digunakan pada asumsi kedua kelompok berbeda (equal variance no assumed). Sedangkan hasil analisis deskriptif dan uji statistik dapat dilihat pada Tabel 6 di bawah ini:

Tabel 6 Hasil analisis data

\begin{tabular}{cccccc}
\hline $\begin{array}{c}\text { Kesembuhan } \\
\text { Pasien }\end{array}$ & Mean & $\begin{array}{c}\text { Std. } \\
\text { Deviasi }\end{array}$ & $\begin{array}{c}\text { Std. } \\
\text { Error }\end{array}$ & p Value & N \\
\hline Rasional & 3.5 & 1.871 & 0.764 & 0.003 & 6 \\
Tidak Rasional & 20.5 & 8.226 & 1.555 & & 28 \\
\hline
\end{tabular}

Berdasarkan Tabel 6 di atas diperoleh rata-rata kesembuhan pasien yang rasional adalah dengan standar deviasi 1.871. Sedangkan untuk kesembuhan pasien yang tidak rasional memiliki rata-rata dengan standar deviasi 8.226. Selanjutnya berdasarkan analisis data untuk melihat perbedaan kesembuhan pasian yang rasional dan tidak rasional diperoleh nilai $\mathrm{p}$ value $=0.003$. Nilai $\mathrm{p}$ value ini $<0.05$, artinya ada perbedaan kesembuhan pasien yang rasional dan tidak rasional pada alpha (0.05) atau taraf kepercayaan $95 \%$.

Pada penelitian Dina Sintia, hasil evaluasi terhadap antibiotika berdasarkan kategori Gyssens memperlihatkan bahwa sebagian besar antibiotika tergolong rasional sebesar $61,0 \%$ sedangkan $39 \%$ termasuk pada kategori tidak rasional. 
Angka tersebut cukup berbeda dibandingkan dengan hasil penelitian theresia, 2011 sebesar 39,6\% rasional dan Amrin sebesar 34\% rasional. Perbedaan ini diperkirakan terjadi karena perbedaan tempat, ruang lingkup, waktu dan metode penelitian (Pamela, 2011).

\section{b. Hubungan rasionalitas dengan hari kesembuhan}

Berdasarkan Lama hari rawat sampai pasien dinyatakan sembuh pada tabel 7. Yang tersingkat adalah 6 hari dan terlama 12 hari, sehingga bisa di buat ratarata hari sembuh $\leq 8$ hari dan $\geq 8$ hari sembuh. Dari lamanya hari sembuh dikelompokkan lagi yang rasional dan yang tidak rasional. Data yang diperoleh diuji dengan Uji Spearman, hasilnya bisa di lihat pada tabel 7.

Tabel 7 Hubungan Rasionalitas dengan Lamanya Hari Sembuh

\begin{tabular}{llc|c|c|c}
\hline & & \multicolumn{4}{c}{ Rasionalitas } \\
\cline { 2 - 6 } & & \multicolumn{2}{c}{ Rasional } & \multicolumn{2}{c}{ Tidak Rasional } \\
\hline Lama Hari & $<=8$ Hari & 4 & $11.8 \%$ & 18 & $52.9 \%$ \\
\cline { 2 - 6 } Sembuh & $>8$ Hari & 2 & $5.9 \%$ & 10 & $29.4 \%$ \\
\hline
\end{tabular}

Pada tabel 7. diatas didapat hasil 52,9\% lama rawat kurang dari sama dengan 8 hari dan 29,4\% lama rawat lebih dari 8 hari. Rata-rata lama rawat yang tertinggi adalah yang tidak rasional dibawah 8 hari lebih banyak pada pasien yang menerima terapi obat tidak rasional. Terlihat belum pas pasien yang menerima pengobatan antibiotik yang tidak rasional sebagian besar lama rawat lebih pendek dibandingkan dengan yang rasional. Berdasarkan Standar prosedur operasional Rumah sakit Salak Bogor minimal pengobatan sepsis neonatal adalah 7 hari.

Untuk menguatkan asumsi diatas, maka dilakukan uji statistik untuk mengetahui hubungan rasionalitas dengan lama hari sembuh dengan Uji Spearman's Rho Correlation. Hasilnya disajikan pada tabel 8.

Tabel 8 Hasil Uji Spearman's Rho Correlation

\begin{tabular}{llrrr}
\hline & & & \multicolumn{2}{c}{$\begin{array}{c}\text { Lama Hari } \\
\text { Sembuh }\end{array}$} \\
\hline \multirow{2}{*}{$\begin{array}{l}\text { Spearman's } \\
\text { rho }\end{array}$} & Rasionalitas & $\begin{array}{l}\text { Correlation } \\
\text { Coefficient }\end{array}$ & 1.000 & .019 \\
\cline { 2 - 4 } & Sig. (2-tailed) &. & .915 \\
\cline { 2 - 4 } & $\mathrm{N}$ & 34 & 34 \\
\cline { 2 - 5 } & Lama Hari & Correlation & .019 & 1.000 \\
& Sembuh & Coefficient & & \\
\cline { 2 - 5 } & Sig. (2-tailed) & .915 &. \\
\cline { 2 - 5 } & $\mathrm{N}$ & 34 & 34 \\
\hline
\end{tabular}

Hasil dari Uji Spearman's Rho Correlation menunjukkan bahwa nilai sig yang didapat sebesar $0.915>0.05$. Hal ini menunjukkan tidak adanya hubungan antara rasionalitas dengan lama hari sembuh. Penggunaan rasional atau tidaknya tidak ada hubungannya dengan seseorang lebih cepat atau lama dalam penyembuhan. 
Untuk mengoptimalkan penggunaan antibiotik secara bijak (prudent use of antibiotics), perlu disusun Pedoman Umum Penggunaan Antibiotik. Pedoman Umum Penggunaan Antibiotik ini diharapkan dapat digunakan sebagai acuan nasional dalam menyusun kebijakan antibiotik dan pedoman antibiotik bagi rumah sakit dan fasilitas pelayanan kesehatan ainnya, baik milik pemerintah maupun swasta (Kemenkes, 2011).

Pada penelitian yang dilakukan oleh (Oktovina, 2011) dikatakan bahwa kualitas penggunaan antibiotik dapat dinilai dengan melihat rekam pemberian antibiotik dan rekam medik pasien. Penilaian dilakukan dengan mempertimbangkan kesesuaian diagnosis (gejala klinis dan hasil laboratorium), indikasi, regimen dosis, keamanan, dan harga. Kementrian Kesehatan melalui Permenkes No. 2406/ MENKES/PER/ XII / 2011, tentang Pedoman Umum Penggunaan Antibiotik mengatur evaluasi penggunaan antibiotika secara kualitatif dengan menggunakan Metoda Gyssen.

Respon pasien terhadap pemberian antibiotika sebaiknya dievaluasi setelah tiga hari pemberian antibiotika tersebut (tergantung diagnosis penyakit). Bila antibiotika yang diberikan tidak memberikan respon, maka harus dievaluasi kemungkinan komplikasi, sumber infeksi lain, resistensi terhadap antibiotika atau kemungkinan salah menegakkan diagnosis (Sudarmo, 2008) dalam (Pamela, 2011). Dina Sintia Pamela dalam penelitiannya mengusulkan agar waktu evaluasi penggunaan antibiotik dijelaskan lebih rinci pada panduan penggunaan antibiotika rumah sakit. Hal itu dapat digunakan sebagai acuan bagi dokter dan apoteker untuk menentukan kapan sebaiknya antibiotika dievaluasi agar pengobatan lebih optimal (Pamela, 2011).

\section{Kesimpulan}

Evaluasi penggunaan antibiotika pada pasien sepsis neonatal dengan menggunakan metoda Gyssens, profil pasien terbanyak penderita sepsis neonatal adalah bayi laki-laki dengan prosentase (59\%), paling tinggi terjadi pada Bayi Berat Lahir Cukup yaitu 62\%. Sepsis awitan dini menempati urutan tertinggi yaitu 59\%. Sepsis neonatal juga terjadi paling banyak pada kehamilan cukup bulan yaitu $79 \%$. Riwayat persalinan normal menempati yang tertinggi yaitu $62 \%$, dan keadaan sewaktu pulang $100 \%$ sembuh. Golongan dan jenis antibiotika yang paling sering digunakan adalah kombinasi ceftriakson-gentamisin dengan prosentase 50\%, rute pemberian melalui intravena dan durasi paling banyak adalah 12 hari. Ketepatan peresepan antibiotika (kategori 0) berdasarkan metoda Gyssens sebanyak 18\%, ada antibiotika yang lebih efektif sebanyak $62 \%$, durasi penggunaan antibiotika kurang dari yang disarankan oleh standar prosedur operasional sebanyak 3\%, Dosis antibiotika yang diberikan tidak sesuai $79 \%$ (lebih dari dosis yang disarankan 32\%, serta kurang dari dosis yang disarankan 47\%). Hasil statistic menunjukkan bahwa nilai sig yang didapat sebesar $0.912>$ alpha 0.05. Hal ini menunjukkan H0 diterima atau tidak adanya hubungan rasionalitas dengan lama hari sembuh. Penggunaan rasional atau tidaknya tidak ada hubungannya dengan seorang pasien lebih cepat atau lebih lama dalam penyembuhan. 
Nanik Patminingsih, Dian Ratih Laksmitawati dan Hesty Utami Ramadaniati

\section{BIBLIOGRAFI}

(Dinkes Jabar), Departemen Kesehatan Jawa Barat. (2012). Profil Kesehatan Provinsi Jawa Barat Tahun 2012.

(IDAI), Ikatan Dokter Anak Indonesia. (2016). Konsensus, Diagnosis dan Tata Laksana Sepsis Pada Anak.

Achadi, Endang L. (2019). Kematian Maternal dan Neonatal di Indonesia. Retrieved June 28, 2020, from Fakultas Kesehatan Masyarakat Universitas Indonesia Jakarta website: https://www.kemkes.go.id/resources/download/info-terkini/rakerkesnas2019/SESI I/Kelompok 1/1-Kematian-Maternal-dan-Neonatal-di-Indonesia

Giofani, Rizki, Oyong, Nazardi, \& Inayah, Inayah. (2016). Evaluation USAge of Antibiotic to Sepsis Neonatus Patient in RSUD Arifin Achmad Province Riau. Riau University.

Haryani, Septiani, \& Apriyanti, Yusna Fadlyyah. (2016). Evaluasi terapi obat pada pasien sepsis neonatal di ruang perinatologi RSUP Fatmawati Januari-Februari tahun 2016. Journal of Fatmawati Hospital, Jakarta.

Kemenkes. (2011). Peraturan Menteri Kesehatan Republik Indonesia nomor 2406/Menkes/Per/Xii/2011 Tentang pedoman Umum Penggunaan Antibiotik. $\begin{array}{llll}\text { Retrieved July } & \text { 9, 2020, from }\end{array}$ https://www.academia.edu/35874924/Permenkes_24062011_Pedoman_Umum_Penggunaan_Antibiotik

Manuaba, Ida Bagus Gde. (2012). Ilmu kandungan, penyakit kandungan, dan KB. Jakarta: EGC.

Oktovina, Magdalena Niken. (2011). ALUR GYSSEN Analisa Kualitatif pada penggunaan Antibiotik. Fatmawati Hospital Journal. Retrieved from http://jurnal.fatmawatihospital.com/pdf/ALURGYSSENAnalisaKualitatifpadapeng gunaanAntibiotik.pdf (Diakses pada tanggal 9 Juli 2020)

Pamela, Dina Sintia. (2011). Evaluasi Kualitatif Penggunaan Antibiotika Dengan Metode Gyssens di Ruang Kelas 3 Infeksi Departemen Ilmu Kesehatan Anak RSCM Secara Prospektif. Depok: Fakultas Kedokteran, Universitas Indonesia.

Para P, Kerja M. (2017). Expanding Maternal and Newborn Survival (EMAS).

Rahmawati, Putri, Mayetti, Mayetti, \& Rahman, Sukri. (2018). Hubungan Sepsis Neonatorum dengan Berat Badan Lahir pada Bayi di RSUP Dr. M. Djamil Padang. Jurnal Kesehatan Andalas, 7(3), 405-410.

Roeslani, Rosalina D., Amir, Idham, Nasrulloh, M. Hafiz, \& Suryani, Suryani. (2016). Penelitian Awal: Faktor Risiko pada Sepsis Neonatorum Awitan Dini. Sari Pediatri, 14(6), 363-368. 
Evaluasi Penggunaan Antibiotika pada Pengobatan Sepsis Neonatal dengan Metoda

Sundani, Ika Popi. (2020). Faktor-Faktor yang Berhubungan Dengan Kejadian Berat Badan Lahir Rendah (BBLR) Pada Petani Bawang Merah di Kecamatan Ketanggungan Kabupaten Brebes Provinsi Jawa Tengah Tahun 2017. Syntax Literate; Jurnal Ilmiah Indonesia, 5(6), 99-119.

Wilar, Rocky, Kumalasari, Ellen, Suryanto, Diana Yuliani, \& Gunawan, Stefanus. (2016). Faktor risiko sepsis awitan dini. Sari Pediatri, 12(4), 265-269.

Wisnumurti, Dewi Anggraini. (2012). Performance of Neonatal Unit, Arifin Achmad Hospital, Pekanbaru. Paediatrica Indonesiana, 52(6), 356-361. 